\title{
Correlation between Fusarium graminearum and Deoxynivalenol during the 2012/13 Wheat Fusarium Head Blight Outbreak in Argentina
}

\author{
J. Palazzini ${ }^{1 *}$, V. Fumero ${ }^{1}$, N. Yerkovich ${ }^{1}$, G. Barros ${ }^{1}$, M. Cuniberti $^{2}$ and S. Chulze ${ }^{1}$ \\ ${ }^{1}$ Facultad de Ciencias Exactas Físico Químicas y Naturales, Departamento de Microbiología e Inmunología, \\ Universidad Nacional de Río Cuarto, Ruta Nacional 36 Km 601, Río Cuarto (5800), \\ Córdoba, Argentina \\ ${ }^{2}$ Wheat and Soybean Quality Lab. INTA-EEA Marcos Juárez, Ruta Nacional 12, Marcos Juárez, \\ Córdoba, Argentina \\ (Received 19 June 2014; Accepted 15 January 2015; \\ Communicated by J. Kolmer)
}

\begin{abstract}
Fusarium graminearum (Schwabe) is reported as the main causal agent of Fusarium head blight in Argentina. The disease causes great losses in humid and semi-humid regions of the world, reducing grain yield and quality. During 2012/13 harvest season, a severe epidemic occurred in Argentina. The aims of this work were to determine the $F$. graminearum incidence and deoxynivalenol accumulation in wheat grain and flour samples obtained from two of the main wheat growing regions from Argentina. Levels of the pathogen and deoxynivalenol content were correlated in heads, grains and flour. Out of 69 wheat grain samples, 55 (79.7\%) showed deoxynivalenol levels between 0.4 and $8.5 \mu \mathrm{g} / \mathrm{kg}$. Fusarium graminearum was the main species isolated, the isolation frequency ranged from 30 to $52 \%$ of the total grains analyzed. Correlations were observed between deoxynivalenol content, $\%$ of $F$. graminearum infection, presence of the pathogen in heads, grain and flour.
\end{abstract} PCR.

Keywords: Fusarium graminearum, deoxynivalenol, Fusarium head blight, quantitative

\section{Introduction}

Wheat (Triticum aestivum L.) is the most important small-grain cereal crop in the world, with an estimated production of 716 million tons in 2013 (FAO 2014). Grain yield and quality of wheat can be affected by several diseases caused either by bacteria or fungi. Among these, Fusarium head blight (FHB) or scab is a destructive disease of cereals like wheat and barley in humid and semi-humid regions of the world. The main pathogen associated with FHB around the world is Fusarium graminearum, which also causes root rot, seedling blight, crown rot and stem rot (Champeil et al. 2004; McMullen et al. 2012). Fusarium graminearum is grouped into phylogenetic lineages (species complex) according to genealogical concordance phylogenetic species recognition (GCPSR) and at least

\footnotetext{
* Corresponding author; E-mail: juanpalazzini@hotmail.com
} 
16 lineages have been described (O’Donnell et al. 2000, 2004, 2008; Starkey et al. 2007; Yli-Mattila et al. 2009; Sarver et al. 2011). Fusarium graminearum is the principal pathogen associated with FHB in wheat in Argentina (Ramirez et al. 2007; Alvarez et al. 2011; Kikot et al. 2011). The pathogen can reduce grain yield and quality and has the ability to produce potent mycotoxins, among them trichothecens, with deoxynivalenol (DON) being the most frequent mycotoxin detected in wheat. DON contamination in small-grain commodities is an increasingly common problem because of the expanded use of "no-till farming" and changing climate patterns (McMullen et al. 2012).

In Argentina, the disease was first described in 1950, since them, a total of $17 \mathrm{FHB}$ outbreaks have occurred from 1960 to 2012 with yield losses estimated up to $70 \%$ in some fields (Moschini et al. 2002; Palazzini et al. 2013). Mycotoxin surveys were started since the epidemic of 1985. Levels of DON contamination detected in 84 grain samples varied from 0.1 to $25 \mathrm{ppm}$ in the 1985 FHB epidemic year (Banchero et al. 1987). A survey of several wheat samples obtained from Santa Fe and Buenos Aires provinces (central wheat growing region from Argentina) during 1986 and 1992 period, showed DON levels between 0.05 and 2.4 ppm (Quiroga et al. 1995). During the 1993 FHB outbreak, Dalcero et al. (1997) reported DON levels up to $4.5 \mathrm{ppm}$ and in the 2001 epidemic, Lori et al. (2003) observed up to 8 ppm in wheat grain samples. During the 2012/13 wheat growing season, a severe epidemic outbreak occurred in the main wheat growing area of Argentina (Palazzini et al. 2013). This FHB epidemic was previously predicted with incidence levels ranging 30 to $100 \%$ for the total wheat growing region by Moschini et al. (2013) based on a previously developed empirical formula to predict FHB in Argentina (Moschini and Fortugno 1996); although predictions did not reveal data on DON contamination of grains. A FHB outbreak is often accompanied by mycotoxin contamination, such as the very stable trichothecene deoxynivalenol, which is not degraded during storage, milling, processing or cooking of food, even during high temperature treatments. This water-soluble toxin, also known as "vomitoxin", is responsible for a wide range of toxicity in animals, including feed refusal, weight loss and vomiting (WHO 2001). All animal species evaluated to date are susceptible to DON according to the rank order of pigs $>$ mice $>$ rats $>$ poultry $=$ rumiants (Pestka 2007). It is also responsible for being citotoxic, inhibit protein synthesis and modulate immune functions (Pestka 2010). Due to its toxicity, international regulations limit the content of DON in food stuffs $(1250 \mu \mathrm{g} / \mathrm{kg}$ for food grain; EC 2007).

Identification of plant pathogens has been historically achieved via conventional methods like visualization of disease symptoms and isolation and identification of the causal agent. The disadvantage of these methods is that the pathogen detection is only possible when the disease is already established and countermeasures are difficult to apply (Osborne and Stein 2007). In contrast, molecular diagnostics of plant pathogenic fungi can be very specific, sensitive, reliable and relatively fast (Klosterman 2012). Competitive PCR and real-time PCR (qPCR) are the two methods currently applied as quantitative molecular diagnostics. In the case of F. graminearum, several TaqMan probes have been developed and used to monitor pathogen dynamics in planta, grains or stubble (Nicholson et al. 1998; Waalwijk et al. 2003, 2004; Reischer et al. 2004). 
In the present study, we aimed to 1) survey for F. graminearum and DON contamination on wheat grain and flour samples collected from two main wheat growing areas from Argentina during the 2012 FHB outbreak; 2) monitor F. graminearum on visually damaged heads through TaqMan Real Time PCR (qPCR); and 3) correlate $F$. graminearum DNA content with DON levels on grains and severity on heads.

\section{Materials and Methods}

\section{Grains and heads sampling}

During 2012/13 wheat harvest season, grain samples were collected from mills and cooperative belonging to the II North (IIN) and V North (VN) wheat subregions from Argentina (Minagri 2013). Sample collection was done by the Wheat and Soybean Quality Laboratory, INTA-EEA Marcos Juárez, Córdoba. A total of 69 wheat samples were collected to analyze DON content and quality parameters. Flour samples were obtained from the respective grain samples at the Wheat and Soybean Quality Laboratory.

Wheat heads were collected from the cultivar BioINTA 3005 (susceptible to FHB) in the IIN wheat subregion. Heads $(n=15)$ showing different severity levels were collected 15 days post-anthesis and freeze-dried. Severity levels were evaluated according to a $0-100 \%$ visual scale (Stack and McMullen 1995). All samples were maintained at $4{ }^{\circ} \mathrm{C}$ until use.

\section{Deoxynivalenol analysis on grain samples}

Grain samples $(n=69)$ were finely ground in a laboratory grinder and homogenized. A subsample $(25 \mathrm{~g})$ was extracted by mixing with $100 \mathrm{ml}$ of acetonitrile:water (84:16, $\mathrm{v} / \mathrm{v}$ ), shaken for $30 \mathrm{~min}$ in oscillatory shaker and then filtered through Whatman No. 4 filter paper. Clean-up was carried out with a Mycosep ${ }^{\mathrm{TM}} 227$ column (Romer Labs Inc., Union, MO, USA), according to manufacturer protocol. Briefly, the filtrate $(8 \mathrm{ml})$ was transferred to a tube and slowly pressed into the interior of the tube with the rubber flange end turned down until $6 \mathrm{ml}$ of the extract had passed through the column. Then, $4 \mathrm{ml}$ of the purified extract was transferred to a vial and evaporated to dryness under nitrogen at $60{ }^{\circ} \mathrm{C}$. The dried residue was then dissolved in $400 \mu \mathrm{l}$ methanol $/$ water $(5: 95 \mathrm{v} / \mathrm{v})$ and DON content was analyzed by HPLC. The HPLC system consisted of a Hewlett Packard model 1100 pump (Palo Alto, CA) connected to a Hewlett Packard 1100 Series variable wavelength detector and a data module Hewlett Packard Kayak XA (HP ChemStation Rev. A.06.01). Chromatographic separations were performed on a Luna ${ }^{\mathrm{TM}} \mathrm{C} 18$ reversedphase column $(150 \times 4.6 \mathrm{~mm}, 5 \mu \mathrm{m}$ particle size $)$ connected to a guard column Security Guard $^{\mathrm{TM}}(4 \times 3.0 \mathrm{~mm})$ filled with the same phase. The mobile phase consisted of methanol/water $(12: 88, \mathrm{v} / \mathrm{v})$, at a flow rate of $1.5 \mathrm{ml} / \mathrm{min}$. The detector was set at $220 \mathrm{~nm}$ with an attenuation of 0.01 AUFS. Injection volume was $50 \mu \mathrm{l}$ and the retention time of DON was $10.1 \mathrm{~min}$. Quantification was relative to external standards of 1 to $4 \mu \mathrm{g} / \mathrm{ml}$ in methanol/water (5:95). The quantification limit was $0.05 \mu \mathrm{g} / \mathrm{g}$. 


\section{Microbiological grain and flour quality analysis}

\section{Determination of DON levels on flour samples}

From a total of 69 samples, 12 flour samples were selected based on the different DON content observed in their respective grain sample. These 24 samples (12 from grains and their respective 12 samples from flours) were used for the rest of the study. The DON analysis on flour samples was determined as described for grain samples.

Fusarium graminearum isolation from wheat grain and flour samples and Fusarium-damaged kernels analysis

From a total of 69 samples, 12 grain and flour samples with different DON content were selected for F. graminearum isolation. Wheat grains (100 grains per sample) were transferred to Fusarium selective medium containing pentachloronitrobenzene (PCNB, Leslie and Summerell 2006). The plates were incubated at $25^{\circ} \mathrm{C}$ for 7 days with a $12 / 12$ photoperiod under cool white and black fluorescent lamps. Single macroconidia were identified with a stereo microscope and transferred to carnation leaf agar (CLA) and potato dextrose agar (PDA), incubated as described above for 15 days for identification according to Leslie and Summerell (2006). Wheat flour $(10 \mathrm{~g})$ was transferred to $90 \mathrm{ml}$ of sterile peptone water, shaken for $30 \mathrm{~min}$ and serially diluted in peptone water $(0.1 \%)$. Colony counting was done from $100 \mu l$ on PCNB selective medium and identified as described above.

Fusarium-damaged kernel (FDK) is a common measure used as indicator of disease severity. A total of 200 grains per sample $(n=69)$ were analyzed and FDK was defined as the percentage of scabby grains (shriveled, pink to white grains, discoloured) present in the sample.

Determination of F. graminearum DNA content on wheat grain and flour samples: quantification by quantitative Real Time PCR (qPCR)

Grain samples $(n=12)$ were pulverized in a miller (Cyclotech, Foss Tecator, USA) and flour samples $(n=12)$ were used for DNA extraction. DNA was extracted from $10 \mathrm{mg}$ of subsamples (pulverized samples or flour) by using the DNeasy 96 plant kit (Qiagen) according to the manufacturer's instruction.

TaqMan qPCR quantifications were done on an ABI Prism 7500 Sequence Detection System (Applied Biosystems). TaqMan reactions were performed in $25 \mu \mathrm{l}$, using $12.5 \mu \mathrm{l}$ of TaqMan universal PCR master mix (Applied Biosystems) and $100 \mathrm{nM}$ of FAM-labeled target and internal control probe and $400 \mathrm{nM}$ of forward and reverse primer for both the target $F$. graminearum (Waalwijk et al. 2004, 2008) as well as the internal positive control (Klerks et al. 2004). TaqMan reactions were performed on $2 \mu 1$ of DNA preparations from samples. Thermal-cycling conditions consisted on a single cycle of 2 min to $50{ }^{\circ} \mathrm{C}$ to degrade uracil containing DNA and 10 min to $95^{\circ} \mathrm{C}$ to inactivate uracil-N-glicosidase, followed by 40 cycles of $95^{\circ} \mathrm{C}$ for $15 \mathrm{~s}$ and $60{ }^{\circ} \mathrm{C}$ for $1 \mathrm{~min}$. A standard curve was gener- 
ated by using 10 -fold serial dilutions of pure DNA in the range of $0.1 \mathrm{pg} / \mu \mathrm{l}$ to $1 \times 104$ $\mathrm{pg} / \mu \mathrm{l}$. Quantifications were always done by duplicate.

Determination of $\mathrm{F}$. graminearum DNA content on wheat heads by $q P C R$

A set of 15 heads showing different FHB severity levels were evaluated. Head samples were pulverized in a miller (Cyclotech, Foss Tecator) before DNA extraction. DNA extraction was performed by using the DNeasy 96 plant kit (Qiagen) according to the manufacturer's instruction.

\section{Statistical analyses}

Pearson correlation coefficient was calculated between DON content on grains and FDK; disease severity on heads and $F$. graminearum qPCR DNA quantification were subjected to an exponential regression. Linear regression and Pearson correlation coefficient were calculated for DON content on wheat grains/flours and F. graminearum qPCR DNA quantification. All the analyses were carried out with Sigma Stat for Windows (version 3.5, SPSS Inc.).

\section{Results}

\section{Deoxynivalenol quantification on wheat grain and flour samples}

High variation on DON content was observed among the 69 wheat grain samples analyzed. A total of 55 samples (79.7\%) showed DON levels ranging from 0.4 to $8.45 \mathrm{ppm}$ $(\mu \mathrm{g} / \mathrm{g})$ and only 14 showed levels below the detection limit $(50 \mu \mathrm{g} / \mathrm{kg})$ (Fig. 1). No differences were observed between the two sub-regions analyzed (IIN and VN). From the 12 flour samples analyzed, 7 showed up to $50 \%$ reduction in DON content in relation to the grain from which were obtained and no reduction was observed in the remaining samples $(n=5)$.

Fusarium graminearum isolation from wheat grains and flour and Fusarium-damaged kernels analysis

From a total of 69 wheat grain and flour samples, 12 were evaluated for F. graminearum infection. On wheat grain samples, high Fusarium spp. contamination was observed ( 77 to $100 \%$ from the total grains analyzed in the samples), F. graminearum being the main species isolated with values ranging 30-52\%. On wheat flour samples, very low Fusarium spp. recovery was observed $\left(<10^{3} \mathrm{CFU} / \mathrm{g}\right)$ and $F$. graminearum was also identified. Fusarium-damaged kernels were evaluated in the 69 wheat grain samples, and averaged $5.77 \mathrm{FDK} /$ sample $( \pm 4.6 \%)$ with a maximum of $13 \%$, a weak correlation was observed between DON content on grains and FDK $\left(\mathrm{r}=0.559 ; \mathrm{R}^{2}=0.312 ; P<0.001\right)$. 


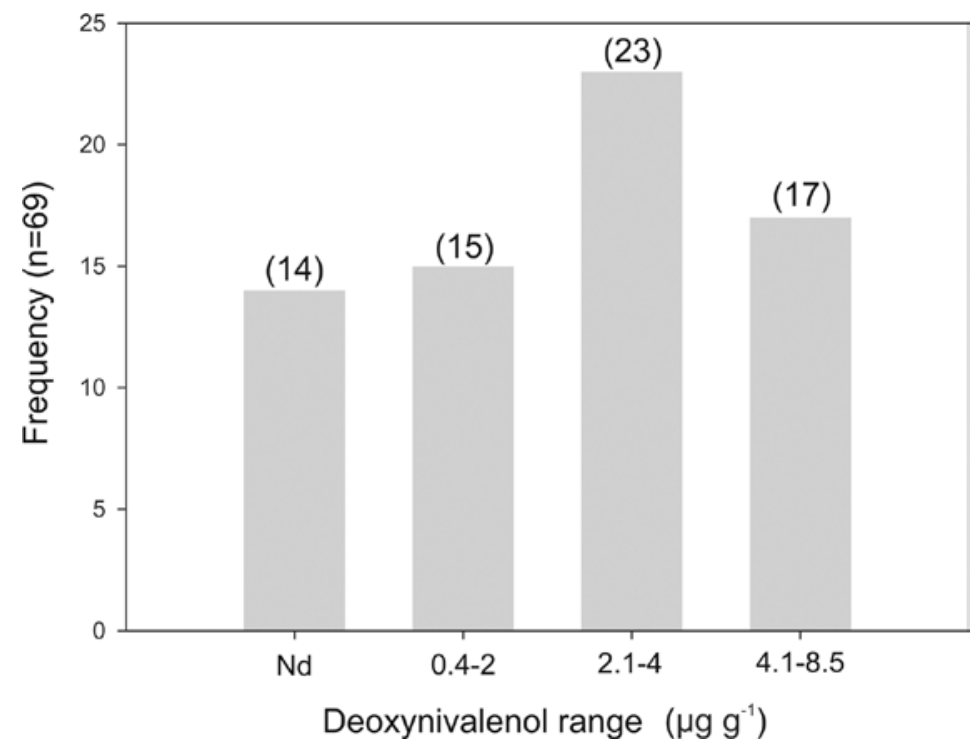

Figure 1. Frequency of DON contamination on grains

Nd: not detected; detection limit: $0.05 \mu \mathrm{g} \mathrm{g}^{-1}$; the number at the top of each column represent the number of samples within each range

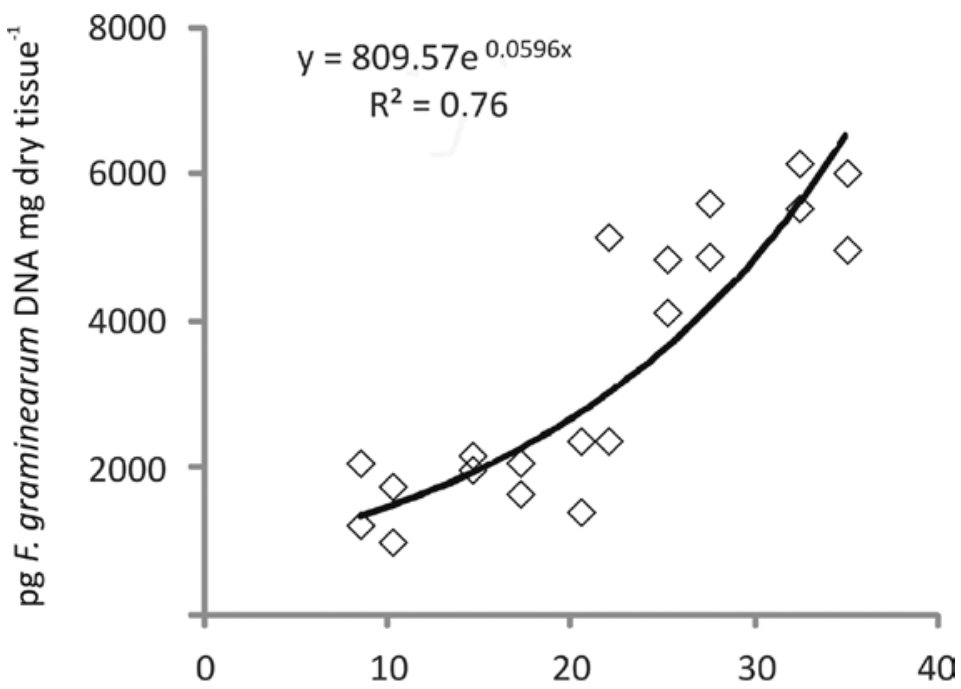

FHB severity in heads (\%)

Figure 2. Exponential correlation between FHB severity and pg F. graminearum DNA detected in wheat heads 
qPCR of $\mathrm{F}$. graminearum DNA in wheat heads, grains and flour

The disease severity of the heads (8-35\%) was strong-positively correlated with the $F$. graminearum qPCR DNA quantification $\left(\mathrm{R}^{2}=0.76 ; P<0.001\right)$. Maximum disease severity observed in heads (35\%) corresponded to an average of 5675 pg DNA (Fig. 2). On wheat grains, a moderate correlation $\left(\mathrm{R}^{2}=0.50\right)$ was observed between DON content and F. graminearum DNA (24-124 pg DNA) (Fig. 3) and no correlation was observed between F. graminearum DNA (2-10 pg DNA) and DON levels on wheat flour (data not shown).

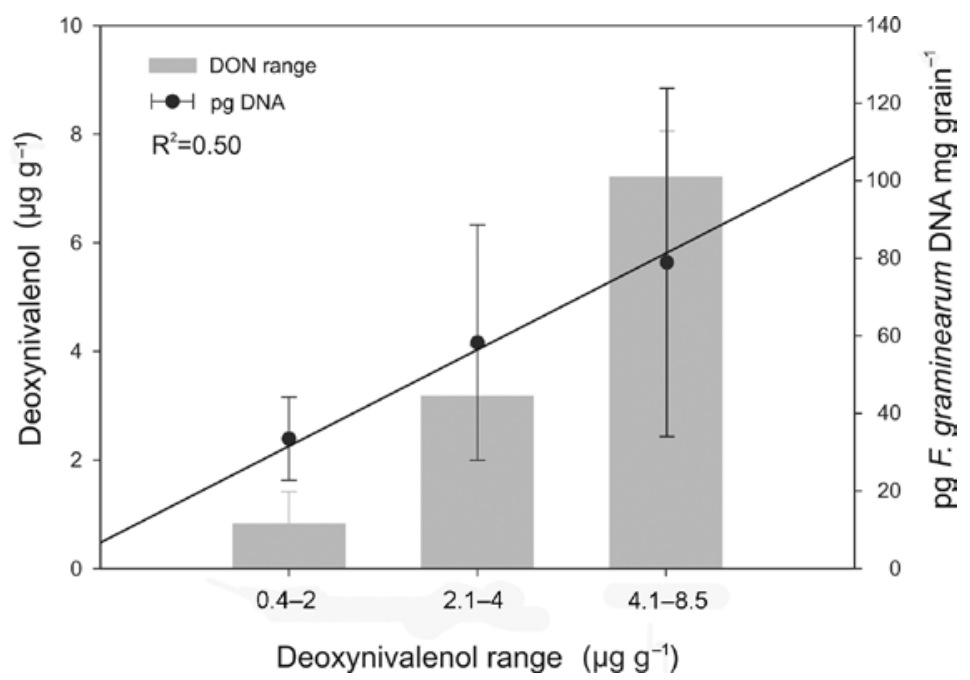

Figure 3. Correlation observed between DON content on grains (ranged) and F. graminearum DNA assessed by qPCR

\section{Discussion}

During the 2012/13 FHB outbreak occurred in Argentina, high levels of F. graminearum contamination and DON accumulation on grains were observed. Most of the samples analyzed were above the maximum DON limit proposed by the EC (2007) and FAO (2004). The DON levels detected in the 2012/13 FHB epidemic year are similar to those detected in previous epidemic years in Argentina (Lori et al. 2003). DON has been reported as the main Fusarium mycotoxin in wheat and by-products in South America; with Argentina, Brazil and Uruguay the countries with available information (Del Ponte et al. 2012; Umpiérrez et al. 2013).

Lori et al. (2003) analyzed the presence of F. graminearum and DON content in different durum wheat varieties from 5 localities in the southern wheat cropping area from Argentina during two years. They observed both DON incidence and levels similar to the 
reported in the present study, with some samples showing DON levels greater than 10 ppm. Also, in other studies from Brazil, Del Ponte et al. (2012) observed high incidence of DON on commercial grain samples collected during 2006/2007/2008, but levels detected were low (mean $0.54 \mathrm{ppm}$ ) and only few samples exceeding commercial limits (the highest was $2.74 \mathrm{ppm}$ ). In a survey during 2000-2003, Malmann et al. (2003) reported DON contamination up to $8.5 \mathrm{ppm}$ in commercial wheat from southern Brazil. In Uruguay, severe outbreaks occurred during 2001, 2002 and 2012, with severe damage and losses in grain yield and quality caused by Fusarium sp. and the presence of DON. Grain contamination was so high that the country had to import wheat grains to fulfill the internal demand (Umpiérrez et al. 2013).

The levels of Fusarium graminearum detected in the present study were similar to FHB incidence predicted by Moschini et al. (2013). In Uruguay, during the severe FHB outbreaks occurred in 2001 and 2002, F. graminearum was also the main pathogen isolated, with 76 and $60 \%$ of the total Fusarium sp., respectively (Pereyra 2003). The 2012 FHB epidemic affecting Argentina was also reported in Uruguay (Umpiérrez et al. 2013). In a previous study, Lori et al. (2003) reported similar levels of $F$. graminearum infection (up to $52.3 \%$ ) during a favorable year for FHB, although strains were isolated from durum wheat in Argentina.

Fusarium-damaged Kernel has been reported as a "subjective" parameter to correlate DON content or F. graminearum infection on grains; for example, Paul et al. (2005) had shown that $53 \%$ of the DON variation in field trials was explained by FDK, suggesting that environmental factors can affect relationship between DON and disease. Del Ponte et al. (2012) also found a low correlation $(\mathrm{R}=0.27)$ regarding DON and FDK on commercial grain samples during 2007. These results are in agreement with our findings since we found no correlation between FDK and DON levels on wheat grains during the 2012 FHB outbreak. On the contrary, Beyer et al. (2007) showed that over $90 \%$ of DON content in artificial combined lots was explained by FDK.

Quantifications of $F$. graminearum DNA by qPCR revealed a strong correlation $\left(\mathrm{R}^{2}=0.76\right)$ when compared with disease severity on wheat heads and a moderate correlation was observed when analyzing DON content on grains $\left(\mathrm{R}^{2}=0.50\right)$. These findings are in agreement with previous results analyzing beta-tubulin gene copies in infected heads (Reischer et al. 2004); but, as far as we know, no reports were done correlating DON content on wheat grains and F. graminearum DNA by qPCR. These measurements could be used as a predictive method to monitor the potential inoculum present in the field that may cause FHB in a future campaign. In addition, results from qPCR could be used to predict the potential level of DON contamination either in the field at preharvest stage or during storage when analyzing DNA from $F$. graminearum by qPCR.

\section{Acknowledgements}

This work was supported by a grant from SECYT-UNRC, PICT 2012-1436 and PIP 112201101-00297 CONICET. 


\section{References}

Alvarez, C., Somma, S., Proctor, R., Stea, G., Mulé, G., Logrieco, A., Fernandez Pinto, V., Moretti, A. 2011. Genetic diversity in Fusarium graminearum from a major wheat-producing region of Argentina. Toxins 3:1294-1309.

Banchero, E., Miguel, M., Godoy, H., Di Giulio, A., Dubois, M., Souto, G., Gomez, M., Resnik, F., Torres, M. 1987. Evaluación de la presencia de Fusarium y de micotoxinas en muestras de trigo de la campaña 1985/86 y su relación con la calidad comercial (Evaluation of Fusarium and Mycotoxins during 1985/86 Wheat Campaign and their Relationship with Commercial Quality). Publicación Gerencia Técnica, Junta Nacional de Granos, Argentina. (in Spanish)

Beyer, M., Klix, M.B., Verreet, J. 2007. Estimating mycotoxin contents of Fusarium-damaged winter wheat kernels. International Journal of Food Microbiology 119(13):153-158.

Champeil, A., Doré, T., Fourbet, J.F. 2004. Fusarium head blight: epidemiological origin of the effecs of cultural practices on head blight attacks and the production of mycotoxins by Fusarium in wheat grains. Plant Science 166:1389-1415.

Dalcero, A., Torres, A., Etcheverry, M., Chulze, S., Varsavsky, E. 1997. Occurrence of deoxynivalenol and Fusarium graminearum in Argentinian wheat. Food Additives and Contaminants 14:11-14

Del Ponte, E., Garda-Buffon, J., Badiale-Furlong, E. 2012. Deoxynivalenol and nivalenol in commercial wheat grain related to Fusarium head blight epidemics in southern Brazil. Food Chemistry 132:1087-1091.

EC 2007. Commission Regulation (EC) $N^{\circ} 1126 / 2007$. Setting maximum level for certain contamination in foodstuffs. Official Journal of the European Union 255:14-17.

FAO 2014. World Food Situation. http://www.fao.org/worldfoodsituation/csdb/en/

Kikot, G.E., Moschini, R., Consolo, V., Rojo, R., Salerno, G., Hours, R.A., Gasoni, L., Arambarri, A., Alconada, T. 2011. Occurrence of different species of Fusarium from wheat in relation to disease levels predicted by a weather-based model in Argentina Pampas region. Mycopathologia 171:139-149.

Klerks, M., Zijlstra, C., Van Bruggen, A. 2004. Comparison of real-time PCR methods for detection of Salmonella enterica and Escherichia coli $\mathrm{O} 157: \mathrm{H7}$, and introduction of a general internal amplification control. Journal of Microbiological Methods 59:337-349.

Klosterman, S. 2012. Real-Time PCR for the Quantification of Fungi In Planta. In: Bolton, M., Thomma, B. (eds.) Plant Fungal Pathogens. Springer Science, London, pp. 121-132.

Leslie, J.F., Summerell, B.A. 2006. The Fusarium Laboratory Manual, Blackwell Professional, Ames, Iowa, pp. 371.

Lori, G., Sisterna, M., Haidukowski, M., Rizzo, I. 2003. Fusarium graminearum and deoxynivalenol contamination in the durum wheat area in Argentina. Microbiological Research 158:29-35.

Malmann, C., Dilkin, M., Mürman, L., Dilkin, P., Almeida, C. 2003. Evaluation of deoxynivalenol contamination in wheat utilized for human consumption. I Pharmacy Brazilian Congress, Sao Paulo, Brazil. Available at: http://www.lamic.ufsm.br/papers/2a.pdf (in Portuguese)

McMullen, M., Bergstrom, G., De Wolf, E., Dill-Macky, R., Hershman, D., Shaner, G., Van Sanford, D. 2012. A unified effort to fight an enemy of wheat and barley: Fusarium head blight. Plant Disease 96(12):17121727.

Minagri 2013. Bread wheat report. Farming, Cattle Raising and Fishing Ministry, Argentina. http://www.minagri.gob.ar/dimeagro/granos/inf-trigo-candeal/trigo_candeal.php

Moschini, R.C., Fortugno, C. 1996. Predicting wheat head blight incidence using models based on meteorological factors in Pergamino, Argentina. European Journal of Plant Pathology 102:211-218.

Moschini, R.C., Galich, M.T.V. de, Annone, J.G., Polidoro, O. 2002. Enfoque fundamental-empírico para estimar la evolución del índice de Fusarium en Trigo (Fundamental-Empirical approach to estimate Fusarium index in wheat). RIA Journal 31:39-53. (in Spanish)

Moschini, R., Martínez, M., Cazenave, G. 2013. Estimación de la distribución espacial de la incidencia de la FET en la región pampeana para la campaña 2012/13 (Estimation of spatial distribution of FHB incidence in Pampa's región during 2012/13 wheat campaign. Argentina). Miscelaneous 125:63-67. (in Spanish) 
Nicholson, P., Simpson, D., Weston, H., Rezanoor, H., Lees, A., Parry, D., Joyce, D. 1998. Detection and quantification of Fusarium culmorum and Fusarium graminearum in cereals using PCR assays. Physiological and Molecular Plant Pathology 53:17-37.

O’Donnell, K., Kistler, H.C., Tacke, B.K., Casper, H. 2000. Gene genealogies reveal global phylogeographic structure and reproductive isolation among lineages of Fusarium graminearum, the fungus causing wheat scab. Proceedings of the Natural Academy Science, USA 97:7905-7910.

O'Donnell, K., Ward, T., Geiser, D., Kistler, H., Aoki, T. 2004. Genealogical concordance between the mating type locus and seven other nuclear genes supports formal recognition of nine phylogenetically distinct species within the Fusarium graminearum clade. Fungal Genetics and Biology 41:600-623.

O’Donnell, K., Ward, T.J., Aberra, D., Kistler, H.C., Aoki, T., Orwig, N., Kimura, M., Bjørnstad, Å., Klemsdal, S. 2008. Multilocus genotyping and molecular phylogenetics resolve a novel head blight pathogen within the Fusarium graminearum species complex from Ethiopia. Fungal Genetics and Biology 45:1514-1522.

Osborne, L., Stein, J. 2007. Epidemiology of Fusarium head blight on small-grain cereals. International Journal of Food Microbiology 119:103-108.

Palazzini, J., Fumero, V., Barros, G., Cuniberti, M., Chulze, S. 2013. Fusarium graminearum y deoxinivalenol en espigas de trigo, granos y subproductos: efecto sobre la calidad e inocuidad. II Workshop Internacional de Ecofisiologia de Cultivos, Mar del Plata, Argentina (Fusarium graminearum and deoxinyvalenol in wheat spikes, grains and flour in Argentina: effect on food safety and quality of wheat grains and byproducts). II International Workshop on Ecophysiology. Mar del Plata, Argentina, p. 26. (in Spanish)

Paul, P., Lipps, P., Madden, L. 2005. Relationship between visual estimates of Fusarium head blight intensity and deoxynivalenol content in harvest what grain: a meta-analysis. Phytopathology 95:1225-1236.

Pereyra, S. 2003. Prácticas culturales para el manejo de la fusariosis de la espiga (Cultural practices in Fusarium Head Blight management). In: Winter Crops Conferences, Uruguay. Diffusion Journal 312:1-9. (in Spanish)

Pestka, J. 2007. Deoxynivalenol: Toxicity, mechanisms and animal health risks. Animal Feed Science and Technology 137:283-298.

Pestka, J. 2010. Toxicological mechanisms and potential health effects of deoxynivalenol and nivalenol. World Mycotoxin Journal 3:323-347.

Quiroga, N., Resnik, S., Pacin, A., Martínez, E., Pagano, A., Riccobene, I., Neira, S. 1995. Natural occurrence of trichothecenes and zearalenone in Argentinean wheat. Food Control 6:201-204

Ramirez, M.L., Reynoso, M.M., Farnochi, M.C, Torres, A., Leslie, J., Chulze, S. 2007. Population genetic structure of Gibberella zeae isolated from wheat in Argentina. Food Additives and Contaminants 24:11151120.

Reischer, G., Lemmens, M., Farnleitner, A., Adler, A., Mach, R. 2004. Quantification of Fusarium graminearum in infected wheat by species specific real-time PCR applying a TaqMan Probe. Journal of Microbiological Methods 59:141-146.

Sarver, B., Ward, T., Gale, L., Broz, K., Kistler, C., Aoki, T., Nicholson, P., Carter, J., O’Donell, K. 2011. Novel Fusarium head blight pathogens from Nepal and Louisiana revealed by multilocus genealogical concordance. Fungal Genetics and Biology 48:1096-1107.

Stack, R., McMullen, M. 1995. A visual scale to estimate severity of Fusarium head blight of wheat. N. D. State Univ. Ext. Serv. Bull. pp. 1095.

Starkey, D.E., Ward, T.J., Aoki, T., Gale, L.G., Kistler, H., Geiser, M., Suga, H., Tóth, B., Varga, J., O’Donnell, K. 2007. Global molecular surveillance reveals novel Fusarium head blight species and trichothecene toxin diversity. Fungal Genetics and Biology 12:1745-1776.

Umpiérrez, M., Garmendia, G., Cabrera, M., Pereyra, S., Vero, S. 2013. Diversity of pathogen populations causing Fusarium head blight of wheat in Uruguay. In: Alconada, T., Chulze, S. (eds.) Fusarium Head Blight in Latin America. Springer Science, Amsterdam, The Netherlands, pp. 15-29.

Waalwijk, C., Kastelein, P., De Vries, P., Kerenyi, Z., Van der Lee, T., Hesselink, T., Köhl, J., Kema, G. 2003. Major changes in Fusarium spp. in wheat in the Netherlands. European Journal of Plant Pathology 109:743-754. 
Waalwijk, C., Van der Heide, R., De Vries, P., Van der Lee, T., Schoen, C., Costrel-de Corainville, G., HauserHahn, I., Kastelein, P., Köhl, J., Lonnet, P., Demarquet, T., Kema, G. 2004. Quantitative detection of Fusarium species in wheat using TaqMan. European Journal of Plant Pathology 110:481-494.

Waalwijk, C., Koch, S., Ncube, E., Allwood, J., Flett, B., de Vries, I., Kema, G. 2008. Quantitative detection of Fusarium spp. and its correlation with fumonisin content in maize from South African subsistence farmers. World Mycotoxin Journal 1:39-47.

WHO 2001 (World Health Organization). Deoxynivalenol. In: WHO Food Additives Series 47. FAO Food and Nutrition Paper 74, Geneva, pp. 419-556.

Yli-Mattila, T., Gagkaeva, T., Ward, T.J., Aoki, T., Kistler, H.C., O’Donnell, K. 2009. A novel Asian clade within the Fusarium graminearum species complex includes a newly discovered cereal head blight pathogen from the Russian Far East. Mycologia 101:841-852. 